\title{
'Grasslands Maku' lotus seed production - research and practice
}

\author{
J. A. Lancashire \\ J. S. GOMEZ \\ Grasslands Division, DSIR, Palmerston North
}

\section{A. McKellar}

Advisory Services Division. MAF, Dunedin

ABSTRACT. The development of successful secd production techniques for the recently released tetraploid cultivar of Lotus pelunculatus Cav. (syn: $L$. uliginosus Schk.; and I. major Scop. Sm.) 'Grasslands Maku' must take account of the distinctive agronomic characteristics of the cultivar. These include slow establishment, particularly in the cool season, slow recovery from defoliation. and poor competitive ability with white clover and other weeds in fertile soils. Spring sowings in cooler areas, a minimum of lenient grazings, and the use of low rates $(0.5$ to $1.0 \mathrm{~kg} / \mathrm{ha})$ of ethofumesate to control white clover in establishing stands arc recommended.

Although shattering of ripe pods can bc reduced by careful harvesting techniques and cutting when 70 to $80 \%$ of the pods have turned brown, some loss of seed is inevitable.

It is suggested that the cultivar should be grown as a specialist secd crop rather than as part of a dual-purpose grazing and seed-production enterprise.

Key words: Seed production, 'Maku' Lolus pedunculotus, ethofumesate. seed harvesting. Trifolium repens.

\section{INTRODUCTION}

There are only two bred cultivars of Lotus pedunculatus Cav. on the most recent OECD List of Certified Hcrbage Cultivars (1979), so it is perhaps not surprising that there is little published information on seed-production techniques for the species. Obviously seed has been successfully produced in different parts of the world, including New Zealand, from local or imported lines (N.Z. Journal of Agriculture, 19 18, 1938) , but unfortunately most of the details appear to have been retained in the minds of the growers and/or seed merchants and not widely published.
Some useful information can be obtained from published material on Lotus conniculatus L. (birdsfoot trefoil), a closely related species which has been grown in many parts of the world (Heath et al.. 1973). However, most of the data in this paper will be concerned with 'Grasslands Maku', a tetraploid cultivar of Lotus pedunculatus Cav. which has been fairly widely grown with somewhat mixed success in various parts of New Zealand during the past 5 years. This species is a perennial legume often seen growing in swampy areas and wet hollows, and traditionally has been widely sown on moist, acid, low-fertility hill country which is not well suited to white clover (Levy, 1970). The major objectives of the breading programme for lotus were Lo improve winter growth and rate of establishment of the species (Armstrong, 1974). However, although th: tetraploid Maku is a considerable improvement on the commercially available types in these aspects (Armstrong, 1974). it is still relatively slow to establish, especially in the cooler temperatures of autumn (Sheath, 1976: Charlton, 1977) It is also very slow to recover from defoliation, particularly when compared with white clover (Brock and Charlton, 1978).

Recent studies have shown that Maku has considerable agronomic potential on acid soils ( $\mathrm{pH}<5.0)$ low in plant nutrients, particularly phosphate, in eroded mountainland (Nordmeyer and Davis, 1977) and tussock grasslands (Lowther, 1977: Scott, 1979) as an alternative legume to white clover, although it has not performed so well at dricr sites at Tara Hills (Musgrave 1977), the Craigicburn Range (Nordmeyer and Davis. 1977) and the Mackenzie Basin (Scott of al.. 1974). The species is also being widely used by the Forest Service with new tree plantings and by the Ministry of Works in soil conservation and highway construction programmes. Similar uses are recommended in the Pacific northwest of 
the U.S.A. (Carlson, 1971). However, Maku's valuable characteristics of tolerance to grass grub (Costelytra zealandica White) (Kain and Atkinson, 1975) and porina (Wiseana cervinata Walker) (Farrell et al., 1974), and its non-bloating properties (Jones ef al., 1970) have not been successfully utilized in farming practice mainly because it does not compete well with white clover (Trifolium repens L.) when soil fertility is suited to that species (Lowther, 1976; Brock and Charlton, 1978).

\section{SEED PRODUCTION}

\section{A REA}

Maku seed crops have been successfully grown from Tongariro National Park in the central North Island to Te Anau in Southland, and apart from areas where annual rainfall is less than $600 \mathrm{~mm}$ (and without irrigation) there appear to be few climatic restrictions on the crop in the main seed-growing areas. However, adequate soil moisture levels are very important during the critical pod-filling period in January-February, and this was well illustrated in the Manawatu in the 1978 drought when one strategically timed irrigation of 6.5 to $7.5 \mathrm{~cm}$ in late January increased seed yields on adjacent farms from $90 \mathrm{~kg} / \mathrm{ha}$ to well over $300 \mathrm{~kg} / \mathrm{ha}$.

In wetter areas there may be severe harvesting difficulties with the crop (see below), and this demonstrates the excellent potential of some of the drier areas of the country where irrigation is available.

A study of the paddock history of the selected area can give useful information on the likelihood of weed infestations by three of the most troublesome species — white clover, sheep's sorrel (Runlex acetosella L.) (mainly a problem in newly developed country), and suckling clover (Trifolium dubium Sibth.) . All produce seed which is very difficult to separate from lotus, and particularly in the case of suckling and white clover also substantially reduce the growth of the crop. White clover has been a constituent of most pasture sowings in New Zealand during the past century, and a countrywide survey by Hyde and Suckling (1953) showed buried seed counts of 6.5 to $16.5 \mathrm{~kg} / \mathrm{ha}$ in lowland pastures with substantial quantities of subterranean clover (Trifolium subterruneum L.) and suckling clover also present in some areas. In order to assess the extent of this problem, samples collected from areas entered for Maku breeders' seed production have recently been analysed for buried seed. Ten to twenty $\mathrm{kg} / \mathrm{ha}$ of white clover seed was found in the top $5 \mathrm{~cm}$ of soil, and although $90 \%$ was dormant (hard), this still leaves approximately $1 \frac{1}{2}$ to 3 million immediately viable seeds/ha. Counts for suckling clover were higher at around $50 \mathrm{~kg} / \mathrm{ha}$ with $80 \%$ of hard seed. These figures indicate the potential problem that these species could pose in Maku seed crops.

\section{Soll Fertility ReQuirements}

Although there is no information on the precise fertilizer requirements of seed crops, there is an increasing quantity of data on the effect of varying nutrient levels on the growth of Maku. Despite the fact that Maku will grow relatively well on acid soils (Lowther, 1977) and at low phosphate levels (Brock, 1973; Nordmeyer and Davis, 1977), this does not necessarily mean that the species will not respond to lime or phosphate applications. For example, the addition of $0.5 \mathrm{t} / \mathrm{ha}$ of lime aided the establishment of Maku on acid soils ( $\mathrm{pH}$ 4.5) in Otago (Scott, 1979), while Brock (1973) showed a $29 \%$ increase in dry matter yield over 3 years on a depleted alluvium with $112 \mathrm{~kg} \mathrm{P} /$ ha/year.

However, these advantages will be partly offset by the fact that white clover will generally be encouraged by the addition of those nutrients, and in the absence of herbicides this is likely to reduce both the current seed production and also the longevity of the Maku sward (Table 1).

TABLE 1: EFFECT OF SUPERPHOSPHATE ON LOTUS/WHITE CLOVER BALANCE (kg DM/ha) IN A SPRING-SOWN MIXED PASTURE (Brock and Charlton. 1978)

\begin{tabular}{ccc}
\hline $\begin{array}{c}\text { Superphosphale } \\
(\mathrm{kg} / \mathrm{ha})\end{array}$ & Lotus & Clover \\
\hline 0 & 2730 & 1860 \\
200 & 1530 & 2710 \\
\hline
\end{tabular}


There may also be a place for small dressings of nitrogen (up to 40 units of $\mathrm{N}$ ) particularly during the establishment period, as Brock (1973) showed that the full development of the N-fixing system took a year in Maku, much longer than for white clover. I. H. Hoglund (pers. comm.) showed in nutrient culture studies that lotus seedlings were more restricted by $\mathrm{N}$ deficiency than white clover, and Charlton and Brock ( 1980) demonstrated a marked response by autumn-sown Maku to a single spring dressing in September of 40 units of $\mathrm{N}$ on moist North Island hill country. However, more frequent dressings severely depressed lotus because of greatly increased grass growth, and obviously this could create (particularly in the absence of herbicides) a serious problem in seed production areas. In Canada, small dressings of nitrogen and phosphate are used to aid the establishment of birdsfoot trefoil seed crops (Twamley, 1970), but little response has been found in established stands (Pankiw, 1970).

As there is so little information on this topic in New Zealand it is possible to make only very general recommendations. However, it would appear useful to use small quantities of nitrogen and phosphate placed in a band by the seed to speed up the development of this slowestablishing species. The disadvantages of the associated increases in grasses and white clover with the resultant need for increased use of herbicides and the possibility of the production of a very large bulk of vegetative material, particularly in wetter areas or seasons, with concomitant harvesting difficulties, are all factors which will have to be considered in the final decision.

\section{Sow ING}

The slow early growth of lotus means that every effort must be made to encourage the rapid establishment of mature plants. The first essential is to thoroughly prepare a firm, well-compacted, fine seedbed and ensure that the seed is inoculated with the appropriate rhizobia just prior to sowing. If the inoculated seed has to be stored for a period and is not coated, the inoculant should be applied to the seed mixed with gum arabic adhesive (Lowther, 1976). The merits of coated or uncoated seed are still unresolved, but Lowther (1976) found no advantage in pelleting lotus oversown on acid tussock soils at three sites in Otago. Also, there is little direct information on the value of broadcast or drill sowings or the use of mixed sowings or cover crops. However, experience suggests that 3 to $4 \mathrm{~kg} / \mathrm{ha}$ of inoculated seed sown in 30 to $60 \mathrm{~cm}$ drills at a maximum depth of 1 to $1.5 \mathrm{~cm}$ without companion species will probably provide the best conditions for the most rapid and easy establishment of the crop.

Maku lotus is much slower to germinate at lower temperatures than most other legumes (Charlton, 1977; Fig. 1), and also shows greater responses to increasing temperatures in the spring than white clover (Mitchell, 1956b). This suggests that autumn sowings will have to be early if lotus is not to suffer severe competition from grasses, white clover and suckling clover, which all have a lower temperature optimum for growth (Mitchell, 1956a; Brock, 1973). A further factor that must be considered in cooler districts is the likelihood that small plants will be uprooted and killed by frost heave (Musgrave, 1977; P. T. P. Clifford, pers. comm.) . Thus it would appear that spring sowings will be more suitable in most parts of the South Island, and at higher altitudes in the North Island, particularly if irrigation is available to offset the adverse effects of a dry spell during the establish-

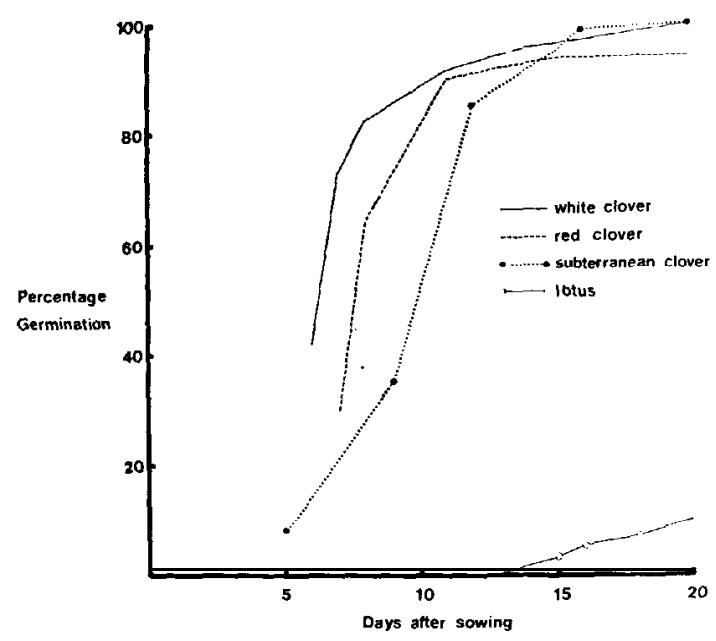

Fig. 1: Germination rates of legume species kept at $5^{\circ} \mathrm{C}\left(16\right.$ h) followed by $10^{\circ} \mathrm{C}(8 \mathrm{~h})$ (Charlton. 1977). 
ment period. In most parts of the North Island early autumn sowings can be attempted, and if weeds are well controlled during the winter a good seed crop can bc obtained in the first year.

Red and white clover are frequently established under cereals or other cover crops, and there could be advantages in developing similar techniques for lotus. However, very few studies have been carried out, although good establishment was achieved under wheat and barley in a wet spring in Takapau, Hawke's Bay (1. M. Ritchie, pers. comm.).

\section{WeEd ContKol}

As lotus is so slow to establish, it is critical to control weeds during this period if the crop is to be established successfully. However, if a weed problem develops despite all the appropriate agronomic procedures being followed, there are a number of herbicides which may be useful. In particular, if paddock history ot buried seed counts indicate a white clover problem, a pre-emergence application of 0.5 $\mathrm{kg} / \mathrm{ha}$ of ethofumesate has proved very successful in controlling the species in autumn sowings in the Manawatu (Brock and Henderson, 1976) (Table 2). In this environment any short-term effects on Maku growth (M. P. Rolston, pers. comm.) had disappeared by the following spring. Higher rates of the herbicide $(1.0 \mathrm{~kg} / \mathrm{ha})$ were required to markedly reduce suckling clover, and these did have a longer-term adverse effect on Maku. If suck-

TARLE 2: EFFECTS OF ETHOFUMESATE, PRE. AND POST-EMERGENCE. ON THE GROWTH OF THREE LEGUMES SOWN IN EOUAL PROPORTIONS IN A MIXTURE (kg DM/ha) (Brock and Henderson, 1976)

\begin{tabular}{crrc}
\hline $\begin{array}{c}\text { Ethofumesate } \\
(\mathrm{kg} / \mathrm{ha})\end{array}$ & $\begin{array}{c}\text { Maku } \\
\text { lotus }\end{array}$ & $\begin{array}{c}\text { White } \\
\text { clover }\end{array}$ & $\begin{array}{c}\text { Suckling } \\
\text { clovel }\end{array}$ \\
$\begin{array}{c}\text { Pre-emergence } \\
0.24\end{array}$ & 420 & 2340 & 200 \\
0.5 & 2305 & 0 & 255 \\
1.0 & $\mathrm{I} 965$ & 0 & 250 \\
2.0 & 1490 & 55 & 75 \\
Post-emerpcnce & 900 & 0 & 355 \\
0.25 & 1170 & 795 & 230 \\
0.5 & 1077 & 410 & 270 \\
1.0 & 1255 & 320 & 110 \\
2.0 & 1365 & 15 & 240 \\
\hline
\end{tabular}

ling clover is a serious problem it may be prefcrable to apply ethofumesate, preemergence, at the low rate and sow in the early spring when Maku will have a better potential fo: rapid growth than the winter-active suckling clover (Brock, 1973) Post-emergence sprays in September were less successful in controlling white and suckling clover (Brock and Henderson, 1976), and this may have been a reflection of rising temperatures reducing the effectiveness of this herbicide (Allen et al. 1974).

A number of studies on the control of other weeds and grasses in the establishing crop in the southern North Island showed that trifluralin and carbetamide at rates of 0.5 and $1.0 \mathrm{~kg} / \mathrm{ha}$, respectively, were promicing preemergence herbicides for grass control, e.g., perennial ryegrass (Lolium perenn I,.) and Poa annua L. (Brock, 1972). 2,4-DB g a ve control of fathen (Chenopodiun album age.), black nightshade (Solanum? nigrum L.), twincress (Coronopus didymus Sm.) and red root (Amaranthus hybridus L.) al rates up to 2 $\mathrm{kg} / \mathrm{ha}$ post-emergence in spring sowings (Tvens. 1975). In the U.S.A., pre-plant soil incorporated EPTC combined with 2.4-DB postemergence is recommended for birdsfoot trefoil seed crops (Burr, 1974), and recent work in the Manawatu suggests that this is a useful combination with autumn-sown Maku. However, if phenoxy resistant broadleaf species such as chickweed (Stellaria mediu Vill.), fumitory (Fumaria officinalis L.), cleavers (Galium aparine L.) a $\mathrm{n} \mathrm{d}$ stinking mayweed (Anthemis cotula L.) are present, joxvnil will give better weed control than 2,4-DB. These preliminarv studies suggest that tolerance levels for establishing Maku could be up to $4.8 \mathrm{~kg} / \mathrm{ha}$ of EPTC $1.6 \mathrm{~kg} / \mathrm{ha}$ of ioxynil and $2.5 \mathrm{~kg} / \mathrm{ha}$ of 2,4-DB (M. P. Rolston and J. D. Henderson, pers. comm.).

There are very few data on the usc of herbicidcs in mature Maku stands. and recent trials by Brock and Henderson (1980) in the Manawatu did not measure the resultant seed production obtained from different herbicide treatments on a 14-month-old crop. However, the results suggest that rates as high as $4 \mathrm{~kg} / \mathrm{ha}$ of ethofumesate and propyzamide applied in winter and spring. and $4 \mathrm{~kg} / \mathrm{ha}$ of asulam and 
2,4-DB in spring, could be used without apparent long-term datnage (growth effects had disappeared by early summer) to the crop. Although these herbicides are capable of control]ing a wide range of weeds including most grasses, particularly barley grass (Hordeum spp.), white clover, suckling clover, docks (Rumex spp.) and sheep's sane], considerably more work is required on factors such as rates, season and variations in different parts of tht country before very specific recommendations can be made. For example, some observations have suggested that there is increased damage to Maku when ethofumesate is applied in frosty weather, whilc an apparently adverse interaction between this herbicide and propyzamide seriously reduced the growth of two 9 . month-old lotus stands in Southland (Brock and Henderson, 1980). It should also be noted that no herbicides have yet been registered with the Agricultural Chemicals Board for use with lotus.

Finally, the fact that some herbicides are registered for ise on other legumes such as white clover does not guarantee their success with lotus. In fact two such chemicals, bentazone and benazolin, are likely to prove lethal, particularly on scedling lotus (M. P. Koiston, pers. comm.).

\section{PEsts}

The tomato fruitworm or corn earworm (Helicoverpa amigera Huebner) h a $\mathrm{s}$ caused serious damage in Maku seed crops in the Waikato and Tongariro National Park. The larvae (caterpillarsl of this pest eat their way into the developing seed pods and destroy the seed. Although it has not been reported in lotus crops in the South Island, the species is found throughout the lowland areas of New Zealand (Valentine, 1975) and has caused sporadic but severe damage in lucerne seed crops in the South Island (Macfarlane and Pottinger, 1976). It is important to watch for the first appearance of sma!l holes in the lotus pods, because a crop may be quickly destroyed by a rapid build-up of the pest in DecemberMarch. It can generally be controlled by trichlorfon, but the Seeds and Apiary advisory officers should be consulted first becouse of possible damage to bees.
Larvae of the common blue butterfly (Zizina otis labradus Godt.) defoliated Maku in mixed pastures in autumn droughts on free-draining soils in the Taupo area (East et al., 1978), and a large build-up of the black aphid (Aphis craccivora Koch) was observed on a Maku seed crop in the Manawatu in 1978 (M. I. Esson, pers, comm.). However, the significance of these pests, and also other aphids on seed production is not known.

\section{Defoliation and Grazing Management}

Sheath (1976) has reported that rhizome development may not occur until 4 to 6 months after spring sowings, and up to 1 year after autumn sowings. Once rhizomes have developed, the plant has a more satisfactory basis for regrowth (Sheath, 1976). but frequent defoliation during establishment may severely delay the process (Scott, 1979) (Table 3).

TABLE 3: EFFECT OF FREQUENCY OF GRAZING ON RHIZOME DEVELOPMENT IN MAKU FOLLOWING OCTOBER OVERSOWING ON ACID TUSSOCK GKASSLAND (Scott, 1979)

\begin{tabular}{|c|c|c|}
\hline & Rhizontes $/ \mathrm{m}^{2}$ & Rhi zone $\mathrm{buds} / \mathrm{m}$ \\
\hline 4 grazings & 60 & 290 \\
\hline i grazings & 350 & 1420 \\
\hline 1 grazing & 660 & 2500 \\
\hline
\end{tabular}

Older stands may also be adversely affected. and the data in Table 4 from a $1 \%$-year-old pure stand of Maku tend to support the suggestion (Brock and Chartton, 1978) that at least 2 years of lenient defoliation may be necessary to develop the persistency required to withstand heavy grazing. However, the generally slow recovery of lotus from defoliation suggests that frequent grazing can rarely be justified because it will give an excellent opportunity for faster-growing weeds to establish in the crops.

The best grazing method is probably a quick mob stocking, with care taken to ensure that the stock do not contaminate the area with white clover seed picked up from theis previous grazing (Suckling, 1952).

In the North Island, autumn-sown crops are unlikely to produce a seed crop in the first 
TABLE 4: EFFECT OF CUTTING HEIGHT ON YIELD OF COMPONENTS OF MAKU $\left(\mathrm{g} / \mathrm{m}^{*}\right)$, APRIL, 1976 (Sheath. 1976)

\begin{tabular}{lccc}
\hline Culting & Above- & \multicolumn{2}{c}{ Underground } \\
\hline Height & ground & Rhi zome & $\begin{array}{l}\text { Crown }+ \text { Adventi- } \\
\text { Taproot } \\
\end{array}$ \\
& & & $\begin{array}{c}\text { tious } \\
\text { Root }\end{array}$ \\
\hline
\end{tabular}

1. 5 c m 103(27.0)* 153(40.0) 109(28.5) 17(4.5) $10.0 \mathrm{~cm} \quad 321(29.5) \quad 423(39.0) \quad 397(36.5) \quad 54(5.0)$

*Percentage of total plant weight in parentheses.

year if they are defoliated. Subsequently, lenient grazings to not less than $5 \mathrm{~cm}$ may be necessary to control the large bulk of herbage which the winter-active Maku can accumulate during the cool season (Armstrong, 1974), but the crop should be closed no later than the end of September.

The same general principles probably apply to spring sowings in the South Island, and P, T. P. Clifford (pers. comm.) has confirmed at Lincoln that seed yield and seed weight of Maku are markedly reduced if the crop is closed later than 1 October (Table 5).

TABLE 5: THE EFFECT OF CLOSING DATE ON SEED YIELD AND SEED WEIGHT OF HANDHARVESTED MAKU AT LINCOLN 1974-5 (P. T. P. Clifford. pers. comm.)

\begin{tabular}{lccc} 
& 10cl. & $\begin{array}{c}\text { Closing Dale } \\
\text { / Nov. }\end{array}$ & 1 Dec. \\
\hline $\begin{array}{c}\text { Seed yield } \\
(\mathrm{kg} / \mathrm{ha})\end{array}$ & 739 & 115 & 0 \\
$\begin{array}{c}\text { Seed weight } \\
(\mathrm{g} / 1000 \text { seeds })\end{array}$ & 1.033 & 0.809 & 0 \\
\hline
\end{tabular}

\section{POLLINATION}

Four hives of honeybees/ha are sufficient to provide a good seed set in a favourable year. However, there is some evidence that honeybees prefer nectar from red and white clover to lotus. Also, in the Manawatu they have been observed working white clover in the cooler part of the day, moving into Maku only when canopy temperatures in the crop reached nearly $30^{\circ} \mathrm{C}$ (E. Roberts, pers. comm.), It appears likely that the virtual failure of an established Maku crop to produce seed at Lincoln in 1975-6 can bc attributed in part to the lack of pollination caused by an average drop of $4^{\circ} \mathrm{C}$ in mean temperatures during November-March compared with the previous year when good seed yields were obtained (Table 5). Flowering in the lotus crop was only slightly reduced, and adjacent white clover areas gave seed set and seed yields consistent with a good level of pollination (P. T. P. Clifford, pers. comm.) .

\section{Time AnD Method of Harvesting}

Time of harvesting is critical if the difficult task of establishing and developing a good, clean stand of Maku is to result in a high yield of seed. The main problem is that because of the extended flowering period of the crop from December to April (Armstrong, 1974) there is always a mixture of varying proportions of flower buds, flowers, and immature, ripe and shattered pods present. Very similar problems are encountered with birdsfoot trefoil in North America (Heath et al.. 1973).

Several years' experience at Palmerston North indicate that the optimum time to cut the crop is when 70 to $80 \%$ of the pods have turned brown. If harvesting is delayed beyond this point the pods will shatter, particularly in hot dry weather, and a large proportion of the crop may be lost in a few hours.

To reduce seed losses it is advisable to cut the crop in the evening, night or early morning while the dew is present in order to reduce shattering. A sicklebar or bottom-driven rotary mower is used to minimize seed loss, and if possible the swath should be rolled into smal! windrows, with the seedheads protected from wind and sun by a cover of the slow-drying thick lotus stems. Weather conditions and the size of the crop will determine when to bring in the pick-up combine, but it may vary from 2 to 5 days, and some losses from shattering of the most mature pods are inevitable.

In unsettled weather and/or in areas prone to wet conditions at this time of the year, the windrowing techniques may be quite unsuitable because the crop is likely to rot on the ground. In these situations the use of a desiccant such as diquat with a surfactant, followed a few days later by direct combining, could be a useful technique, although it does not appear to have been very successful in New Zealand mainly because of the difficulty of getting a 
good kill of the material in a bulky crop. Further work on this procedure is required, but Twamley (1970) pointed out that it was difficult (with birdsfoot trefoil) to get the right combination of ideal weather, good timing and a capable manager to ensure the success of the technique.

\section{Seed Cleaning}

The seed weight of Maku (0.6 to $0.8 \mathrm{~g} / 1000$ seeds) is similar to white clover, and therefore it is very difficult to separate the two species in seed cleaning, although limited success has been achieved on a textured surface separator and a spiral separator by utilizing the different shapes of the two types of seed.

\section{CONCLUSION}

Seed yields of 200 to $400 \mathrm{~kg} / \mathrm{ha}$ have been regularly obtained by Grasslands Division in the Manawatu, but farm yields throughout New Zealand have varied from 0 to $300 \mathrm{~kg} / \mathrm{ha}$, with a good average probably being about $100 \mathrm{~kg} / \mathrm{ha}$. However, at current retail prices of $\$ 13 / \mathrm{kg}$ this is still an attractive proposition. For example, the Lands and Survey Department has easily covered the cost of land development in the Te Anau area with a Maku seed crop of $100 \mathrm{~kg} / \mathrm{ha}$ (D. Paterson, pers. comm.).

Finally, most of the data presented suggest that, at least until more experience is gained, Maku lotus must be treated as a specialist seed crop if reasonable yields are to be obtained. Only very limited grazing is possible and the crop will not be successful if growers attempt to produce seed on the traditional dual-purpose basis of seed and stock production frequently used with red and white clover.

\section{ACKNOWLEDGEMENTS}

Valuable discussions were held with Philip Rolston, John Brock and Deric Charlton, Grasslands Division, DSIR, Palmerston North; Robin Scott and Bill Lowther, Invermay Agricultural Research Centre, MAF, Mosgiel; and Gavin Sheath, Whatawhata Hill Country Research Station, MAF, Hamilton. Meryll Bloomfield and Mike Barber, Grasslands Division, did the buried seed counts, and many MAF Seeds Advisory Officers collected the samples.

\section{REFERENCES}

Allen, F. C.; Hartley, M. I.; Meeklah, F. A., 1974. Proc. N.Z. Weed and Pest Control Conf., 27: 85-9.

Armstrong, C. S., 1974. N.Z. /l exp. Agric., 2: 333-6.

Brock, I. L.. 1972. Weed Res., 12: 144-9. 1973. N.Z. II agric. Res., 16: 483-91.

Brock, J. L.; Charlton, J. F. L., 1978. Proc. N.Z. Grassld Ass., 39: 121-9.

Brock, J. L.; Henderson, J. D., 1976. Proc, N.Z. Weed and Pest Control Conf., 29: 93-6.

1980. Ibid. (in press).

Burr, R., 1974. In Oregon Weed Control Handbook pp. 46-7. Oregon State University,

Carlson, J. R., 1971. Ann. Meet. Oregon Seed Growers League. 37: 5-6.

Charlton, J. F. L.. 1977. N.Z. Il exp. Agric., 5: 385-90.

Charlton, J. F. L.; Brock, J. L., 1980. Ibid. (in press)

East, R.; Watson. R. N.; Welsh, R. D.. 1978. N.Z. Entomologist. 6: 390-I.

Farrell. J. A. K.; Sweney, W. I.; Jones, A. E., 1974. N.Z. /l ugric. Res.. 17: 375-8.

Heath, M. E.: Metcalfe, D. S.; Barnes, R. F., 1973 In Forages. Iowa State University Press.

Hyde, E. 0. C.; Suckling. F. E. T., 1953. N.Z. Il Sci. Technol., 34A: 375-85.

Ivens, G. W., 1975. Proc. N.Z. Weed and Pest Control Conf., 28: 31-4.

Jones, W. T.; Lyttleton. J. W.: Clarke, R. T. J., 1970. N.Z. /l ogric. Res., 12: 149-56.

Kain, W. M.; Atkinson, D. S., 1975. Proc. N.Z. Grassld Ass., 37: 132-7.

Levy, E. B., 1970. Grasslands of New Zealand. Government Printer, Wellington.

Lowther, W. L., 1976. Proc. N.Z. Grassld Ass., 37: 221-7.

1977. Ibid.. 38: 133-9.

Macfarlane, R. P.; Pottinger. R. P.. 1976. Proc. N.Z Weed and Pest Control Conf., 29: 19-22.

Mitchell, K. I., 1956a. N.Z. Il Sci. Technol., 38A: 203-2 16.

- 1956b, /bid., 38 A: 395-413.

Musgrave, D. I., 1977, Proc, N.Z. Grussld Ass.. 38: 126-32.

Nordmeyer, A. H.; Davis, M. R., 1977. Ibid., 38: 1 19-25.

Pankiw, P., 1970. Mgmt Sheet. Res. Sta., Beaverlodge, Alberta.

Scott, D.; Stringer, G. C.; O'Connor. K. F.: Clifford, P. T. P.. 1974. N.Z. // exp. Agric.. 2: $251-9$.

Scott, R. S., 1979. Aglink //2000/2/79: FPP204.

Sheath, G. W.. 1976. Pror. N.Z. Grussld Ass.. 37: 215-20.

Suckling, F. E. T., 1952. N.Z. /l Sci. Technol., 33A: 64-77.

Twamley, B. E., 1970. Newsletter. Crop Sc. Dept., Univ. of Guelph.

Valentine. E. W.. 1975. DSIR/nf. Ser.. No. 105/9. 